\title{
Geographical Distribution and Incidence of Orchardgrass Choke, Caused by Epichloë typhina, in Oregon
}

\author{
W. F. Pfender and S. C. Alderman, USDA-ARS National Forage Seed Production Research Center, 3450 S.W. \\ Campus Way, Corvallis, OR 97331
}

\begin{abstract}
Pfender, W. F., and Alderman, S. C. 1999. Geographical distribution and incidence of orchardgrass choke, caused by Epichlö̈ typhina, in Oregon. Plant Dis. 83:754-758.

A 1998 survey was conducted in the Willamette Valley of Oregon, the major U.S. production area for orchardgrass seed, to determine the extent and severity of choke disease in Dactylis glomerata. This disease is a severe constraint to orchardgrass seed production in other parts of the world, but was unknown in Oregon prior to 1997. Thirty-seven fields, representing 27 cultivars and the geographical extent of production in the Willamette Valley, were selected from a list of fields registered for certification. Choke was found in $26(70 \%)$ of the fields, and disease incidence ranged from $<0.05$ to $28 \%$ tillers affected. Five of the 37 fields had only trace levels of the disease, but four of the fields, representing three counties, had incidences $>10 \%$. In a survey of 16 fields located within $3.5 \mathrm{~km}$ of the 1997 discovery, choke was found in 14 fields, of which three had incidences $>20 \%$. Increase in disease incidence between 1997 and 1998 ranged from 2.1- to 3.3-fold in the three fields where disease increase was measured. One year after its presence was confirmed in Oregon, choke disease of orchardgrass is well-established throughout the orchardgrass seed producing region at damaging levels and is apparently able to increase and spread under the prevailing climatic and cultural conditions.
\end{abstract}

Additional keywords: emerging diseases, endophyte

Epichloë typhina is an endophytic fungal symbiont of several Poiod grasses (16), including orchardgrass (Dactylis glomerata) (15). Symptoms are manifested near the time of flowering, when growth of the fungus physically prevents ("chokes") the emergence of the grass inflorescence (5). Therefore, although the disease is not economically significant to the use of orchardgrass as forage, it has a severe effect on orchardgrass seed production. In France, incidence of choke commonly reaches $30 \%$ in an orchardgrass field by the fourth year of seed production, making the stand unprofitable (10). In the Willamette Valley of Oregon, where approximately $95 \%$ of the orchardgrass seed produced in the United States is grown and fields commonly remain productive for a decade or more, orchardgrass choke was until recently unknown. This situation has changed, however, with the recent appearance of the disease in the Willamette Valley. First noticed as a single, unconfirmed specimen from a postharvest field in 1996 ,

Corresponding author: W. F. Pfender

E-mail: pfenderw@ucs.orst.edu

Accepted for publication 5 May 1999.

Publication no. D-1999-0524-01R

This article is in the public domain and not copyrightable. It may be freely reprinted with customary crediting of the source. The American Phytopathological Society, 1999. the presence of the disease was verified in several fields of one cultivar in 1997 (1). The discovery was made shortly before harvest, however, and there was not sufficient time for a thorough survey of orchardgrass fields in 1997.

The causal agent of orchardgrass choke is closely related to Epichloë species that cause choke in other cool-season grasses, as well as to non-choke-inducing endophytic fungi belonging to the form-genus Neotyphodium (formerly Acremonium section Alba-lanosa). Currently, there are 10 species (mating populations) recognized within the genus Epichlö̈ (12). Four of these are symbiotic with North American grasses, whereas the other six species, including E. typhina, form associations with grasses of Eurasian origin. E. typhina is unusual among Epichlö species in having a broad host range that includes species in several grass tribes (8). Within E. typhina, there exist strains with differing host ranges: Chung et al. (4) presented evidence that isolates from Lolium perenne do not form a stable symbiosis with $D$. glomerata, and vice versa. Epichloë festucae is a recently designated species (9) that was formerly included in E. typhina; its host range includes several fine fescues such as the Festuca rubra grown in the Willamette Valley, but not orchardgrass or perennial rye grass.

Although Epichlö̈ and Neotyphodium species are all endophytes with their grass hosts, there are important differences among their life cycles and host-fungus associations (2). Whereas all these endophytes grow systemically within a host during its vegetative and reproductive growth, the non-choke-inducing endophytes (Neotyphodium spp.) cause no external symptoms. They grow into the aleurone layer of the developing grass seed, by which they are transmitted to the next host generation (vertical transmission), but do not produce a sexual stage and cannot move from one infected plant to another of the same generation. These endophytes therefore are mutualistic with their hosts. In contrast, the choke-inducing endophytes do not remain cryptic in their hosts, but undergo a sudden burst of mycelial growth around the developing floral apex and grow out through the enveloping leaf sheaths to form a stroma on the external plant surface $(5,6)$, preventing the host from flowering. Infection of healthy plants by these antagonistic endophytes generally occurs via the ascospores produced on the stroma. For most choke-inducing strains of Epichloë, this infection occurs when ascospores land on floral parts and produce infective conidia that penetrate to the developing seed $(3,5)$, which carries the infection to the next host generation. Two Epichloë species, E. festucae and E. sylvatica, can be transmitted either via floral infection by ascospores or via vertical transmission to seed such as occurs with Neotyphodium $(8,11)$. E. typhina rarely permits the host inflorescence to form, and infects primarily by ascospores. There is some uncertainty, however, regarding the infection court, which may be the flowers at anthesis and/or the cut ends of stems after harvest.

Given the importance of the Willamette Valley as a production area for orchardgrass seed, and the potentially devastating effects of choke on that production, it is important to determine the current status of this newly emergent disease in Oregon. Therefore, we conducted a survey to determine the geographical distribution, incidence, and severity of choke among cultivars grown in the Willamette Valley. We also obtained data regarding the potential for this disease to increase under Oregon conditions.

\section{MATERIALS AND METHODS}

Selection of fields. To determine geographic and cultivar distribution of choke in the seed production area, 37 orchard- 
grass fields were chosen from a list of 320 fields registered for 1998 certification in Oregon. Fields were arbitrarily selected to include a range of cultivars and the geographic extent of production in the Willamette Valley. The fields in this valleywide survey represented six of the eight counties in which orchardgrass is grown; these counties accounted for approximately $95 \%$ of the certified orchardgrass acreage in 1998. Twenty-seven of the 53 certified cultivars being grown that year were represented in the selection. Individual field size varied from 0.5 to 85 ha, but the total acreage in the 37 fields contained $10 \%$ of the total Oregon certified orchardgrass acreage for 1998 and $6 \%$ of all orchardgrass acreage grown for seed in Oregon that year. An additional nine fields were included in a second survey to determine distribution of choke in fields within a $3.5-\mathrm{km}$ radius of the heavily infested fields observed in 1997. Seven of the fields for the valleywide survey were also in this area, with the result that we surveyed 16 fields in the vicinity of the observed 1997 infestation. The total of all fields surveyed (46) included $12 \%$ of the orchardgrass acreage and $55 \%$ of the cultivars under certification for 1998.

Survey method. Each field was surveyed once in 1998 between 12 and 27 June by examining 40 locations per field. A rectangular frame $(0.25 \times 1.0 \mathrm{~m})$ made of PVC pipe was used to delineate each $0.25 \mathrm{~m}^{2}$ sample site. Ten sites were chosen along each of four diagonal transects per field; sites were approximately equidistant along the transects and were chosen arbitrarily by dropping the frame after a predetermined number of steps chosen according to the surveyor's estimate of field size. All choked stems for which the stroma was included inside the frame were counted. In addition, two to four estimates of the total number of reproductive tillers per $0.25 \mathrm{~m}^{2}$ were made in each field. The 40 choke observations per field were combined to produce the total number of choked tillers per $10 \mathrm{~m}^{2}$, and the percentage of choked tillers was calculated from this value and the average number of total tillers per unit area. During the survey in each field, surveyors also noted the presence of choked tillers not included in the 40 samples. If all 40 grids were negative for choke, but other choked tillers were observed in the field, the field was assigned a value of $<1$ choked tiller per 10 $\mathrm{m}^{2}$ and a percent choke of $<0.05 \%$. If no choke was observed, a value of $0 \%$ was assigned.

Year-to-year increase. In 1997, when the disease was discovered in three fields just prior to harvest, these fields were immediately surveyed for incidence of choke. In these cases, $0.25 \mathrm{~m}^{2}$ samples were examined as previously described, except that 16 samples were collected on each of two transects (total of 32 samples per field). In the 1998 survey, the same three fields were first surveyed on two transects taken in approximately the same locations and sampled at the same intervals as the 1997 transects. We estimate that any given 1998 sample was taken within a 5-m radius of the corresponding 1997 sample. A comparison could therefore be made between sequentially arranged data of 1997 and 1998 to show change in choke incidence in these particular locations of the fields. Differences between 1997 and 1998 choke levels were tested by a nonparametric procedure, the Wilcoxson signed rank test, performed with the Statistix software package (Statistix Version 3.1, NH Analytical Software, St. Paul, MN). In order to include these three fields in the 1998 overall survey data, four transects of 10 samples each also were taken as described in the "survey method" section, and these results were collated as part of the survey results.

\section{RESULTS}

Between 12 and 27 June, when the survey was conducted, E. typhina was observed almost exclusively in its teleomorphic state. Perithecia yielded septate, filamentous ascospores with a length of $156 \pm 25 \mu \mathrm{m}$ (mean \pm 1 standard deviation measured on 25 spores mounted in water).

Choke was detected in $70 \%$ (26 of 37) of the arbitrarily selected orchardgrass

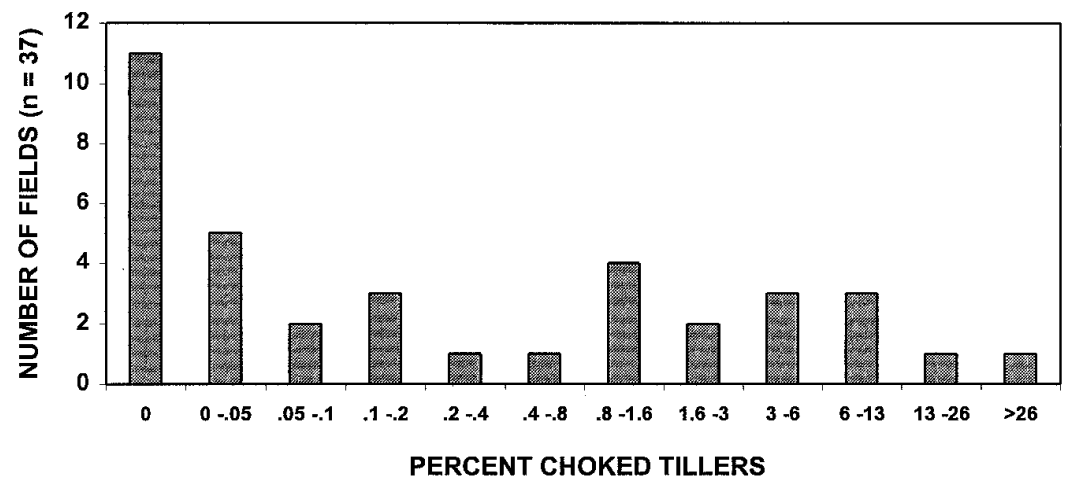

Fig. 1. Distribution frequency of choke incidence (\% tillers affected) in 37 arbitrarily selected fields of Oregon's Willamette Valley. Forty samples, $0.25 \mathrm{~m}^{2}$ each, were assessed in each field. fields in the valley-wide survey (Fig. 1). Approximately $14 \%$ of the fields had very low levels $(<0.05 \%)$ of choke, $46 \%$ of the fields had incidences of 0.05 to $10 \%$, and four of the 37 fields had incidences $>10 \%$. Averaged across the 37 fields, the number of total tillers (healthy plus diseased) per $\mathrm{m}^{2}$ was 277 (standard deviation = 66); therefore, $10 \%$ incidence is approximately 28 choked tillers per $\mathrm{m}^{2}$. Twenty-two of the 27 cultivars surveyed were infected. Six cultivars were represented by more than one field each, and at least one field of each of these cultivars was infected. The disease was detected in five of the six counties surveyed (Fig. 2A). The one county without a choke record (Lane County) has relatively little orchardgrass acreage and was represented in the survey by a single field. Later reports from extension personnel indicated at least one nonsurveyed field in Lane County was infested with choke in 1998.

Fourteen of 16 orchardgrass fields surveyed $(94 \%)$ within a $3.5-\mathrm{km}$ radius of the 1997 disease observation were infested to some degree with choke disease (Fig. 2B). Five of these fields were infested at $>10 \%$ incidence. The most severely affected fields (>20\% incidence) were in very close proximity to each other and were all of the same cultivar, but had been planted in several different years between 1991 and 1995. Another cultivar in this area had disease incidences varying from 0 to $8 \%$ among the eight fields planted to it. At a distance of $2.5 \mathrm{~km}$ north of the most heavily infested fields, incidence was $<2 \%$, but another field located $1.0 \mathrm{~km}$ further north had $12 \%$ choke.

When data from 1997 and 1998 transects on three fields were arranged by approximate sample location (Fig. 3), it appeared that choke incidence increased during this 1 -year period. The Wilcoxson signed rank test of these data confirmed the differences to be significant at the 0.05 level (Fig. 3). The total number of tillers per $\mathrm{m}^{2}$ in these three fields was not significantly different between years, and averaged 300. Thus, the increases from 1997 to 1998 along the two transects in these three fields were: from 13 to $35 \%$ (2.7-fold), from 9 to $19 \%$ (2.1-fold), and from 3 to $10 \%$ (3.3-fold).

\section{DISCUSSION}

We have demonstrated with this survey that choke disease in orchardgrass, unknown in Oregon before 1997, is now established and widespread in the Willamette Valley. This disease has the potential to be a very serious problem for orchardgrass production in the US for two reasons: (i) disease incidence and yield loss are directly correlated (7); and (ii) the rapid year-to-year increase in incidence observed in Europe $(7,10)$ can occur in Oregon, at least under some conditions (Fig. 3). 


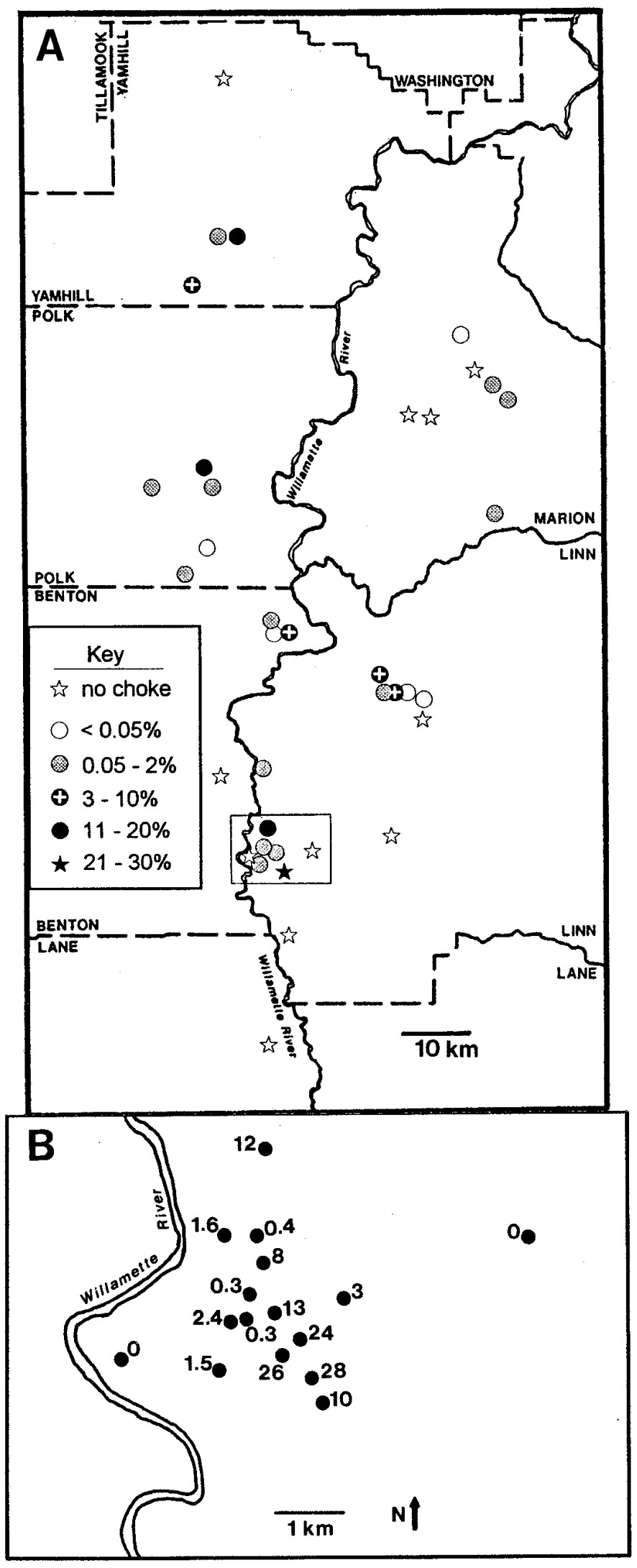

Fig. 2. Locations and choke incidences of surveyed fields. (A) Location and choke incidence class of 37 orchardgrass fields observed in valley-wide survey, June 1998. Each value is the mean of 40 samples per field. (B) Location and 1998 choke incidence (\% tillers affected) in 16 orchardgrass fields including and immediately surrounding the site of choke discovery in 1997. The 16 fields include seven shown in Figure 2A plus nine additional fields and are located within the area delineated by a box in Figure 2A. Location of the three fields where choke was discovered in 1997 (10, 28, and 26\% in Fig. 2B) is approximately $44.377^{\circ} \mathrm{N}, 123.193^{\circ} \mathrm{W}$.
The presence of choke disease in orchardgrass represents an introduction of the pathogen from outside the region, and perhaps from outside the continent. Before our initial report (1), the only previous record of orchardgrass choke in North America is a listing by Sprague (13) for the disease in New Jersey, and there is no description of the pathogen in the report, nor an indication of whether the teleomorphic stage was present. E. typhina is symbiotic only with grasses of Eurasian origin (12) and is not native to North America. Although another species of European origin, E. festucae, is regularly observed at low frequency on fine fescues in the Willamette Valley, its presence is not likely related to the occurrence of orchardgrass choke. $E$. festucae, although formerly included within the species E. typhina, does not infect orchardgrass (9); furthermore, the teleomorph of $E$. festucae has not been reported in Oregon. The introduction of $E$. typhina may have been via infected seed (if the pathogen proves capable of seed transmission) or vegetative material.

To determine the means by which this pathogen was introduced, and to develop methods to manage it, we must understand the infection process. Specifically, the occurrence and relative importance of floral infection and stem infection must be known. Western and Cavett (15) attempted to transmit the fungus by conidia or ascospores and via several infection courts. They were unable to produce infected seeds, although they inoculated flowers with ascospores or conidia. Their only successful inoculations were achieved by inoculating the pith of cut stems with ascospores. Under this scenario, stems cut at harvest would provide the infection court, and the pathogen would overwinter in plant crowns and grow endophytically as the plant elongates in the spring. Western and Cavett (15) found no evidence of seedborne E. typhina in orchardgrass and noted that in England the period of ascospore release occurred after host anthesis, reducing the likelihood of floral infection as a common occurrence. More recently, however, Chung and Schardl (5) demonstrated floral infection of some hosts by ascospores of E. typhina. Although they did not test infection of orchardgrass, they did demonstrate floral infection of perennial ryegrass (Lolium perenne) by a closely related strain of E. typhina as well as by ascospores from a cross of the strains from Lolium and Dactylis. In our field surveys, we noted (unpublished observations) a case in which one field with no observed choke had been planted from the same 1994 seed lot as another field in which a high incidence of choke was observed; no choke was observed in the source field for the seed lot. From the experiments conducted by Western and Cavett (15), and from our observations, it seems likely that infection through cut stems occurs in Ore- 

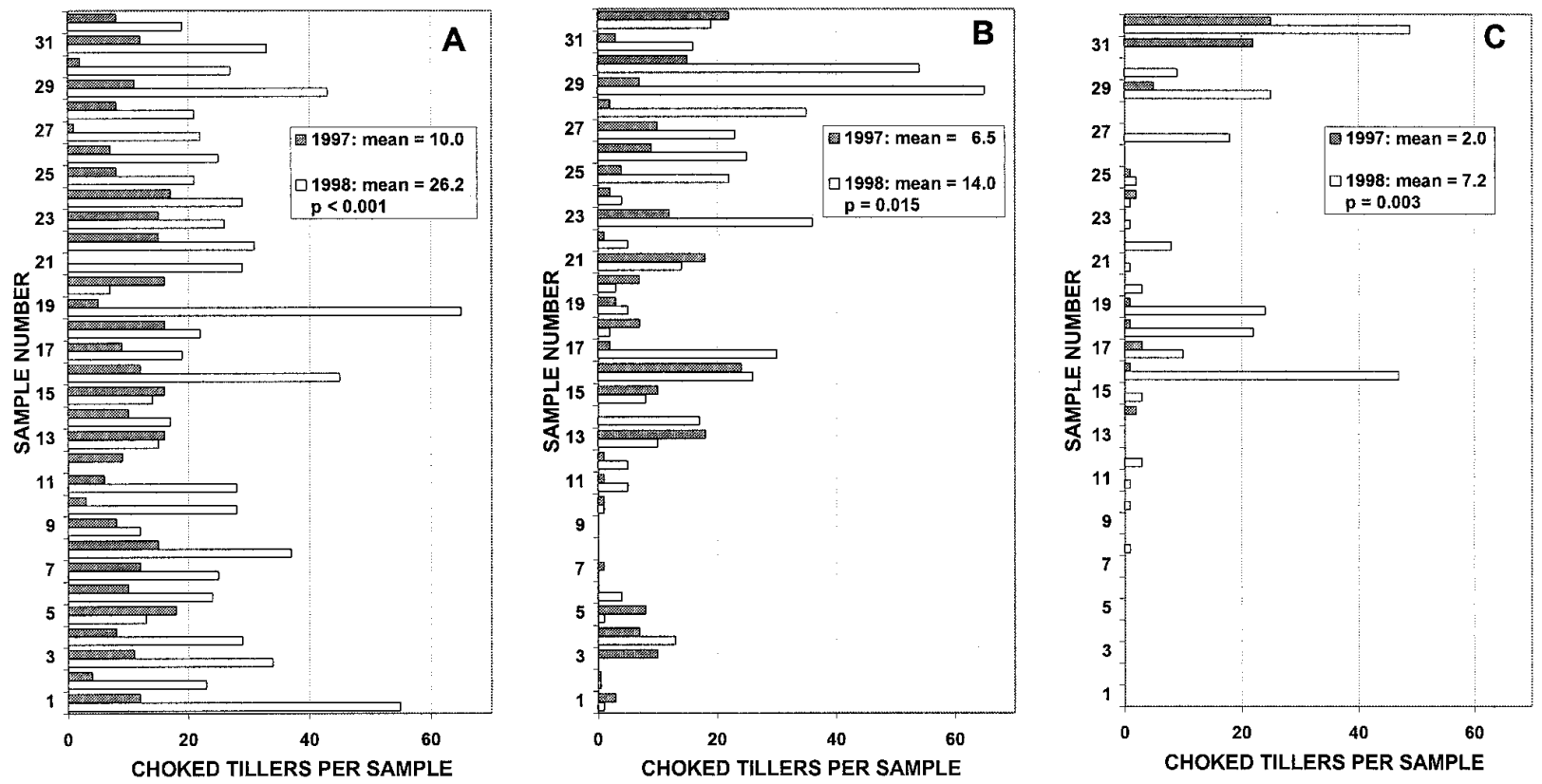

Fig. 3. Comparison of 1997 and 1998 levels of orchardgrass choke (affected tillers per $0.25 \mathrm{~m}^{2}$ sample) in three fields (A, B, and C). Samples were observed along transects in approximately the same locations (sample number) in 1998 as in 1997. Overall mean number of choked tillers per sample in each year $(n=32)$ and result of Wilcoxson signed-rank test are given in figure legends.

gon. Further experiments are required to verify this and to determine whether seed infection occurs and its relative importance under Pacific Northwest conditions.

The pattern of occurrence of orchardgrass choke in the Willamette Valley (Fig. 2A) does not suggest dispersal from a single point of introduction. We observed heavily infested fields ( $>10 \%$ incidence) scattered many kilometers apart across three counties. Delicate, hyaline ascospores are released during the night (10) and are presumably dispersed by wind. The concentration of moderate and severe infestation in and to the north of the fields where it was observed in 1997 (Fig. 2B) suggests dispersal of the pathogen on southerly winds that commonly accompany the rare instances of rainy summer weather in the area.

It is unknown how long orchardgrass choke has been present in the Willamette Valley. It may have been present for many years at low levels, then released from suppression by the recently mandated reduction in postharvest field burning. Because one reported route of infection is through the cut stubble after harvest, burning in previous years might have destroyed the pathogen in the infection court and kept the disease in check. There are currently no data to support this proposition, but field experiments are in progress to investigate the impact of burning or nonthermal management practices, such as reclipping the stubble after the seed is harvested, on disease suppression. Whether burning affects disease progress or not, it seems unlikely that choke has been present for more than a few years. Certified seed fields are closely scouted, and the striking visual appearance of choke would make it difficult to overlook.

Factors controlling disease increase and spread in the area are not yet known and obviously depend upon how and where infection occurs. We noted examples of adjacent fields of the same cultivar that differed markedly in choke incidence. For infections occurring through cut stubble, such field-to-field differences could result from the fields having been harvested on different dates with attendant different weather conditions. If seed infections occur through the flowers, field-to-field differences in the amount of seed shatter (and thus amount of infected volunteer seedlings) could be responsible for differences in choke incidence.

It should be noted that although orchardgrass choke reduces seed yield, it does not reduce the quality of forage seed produced. The pathogen has not been shown to be seed-borne (15) and does not affect vegetative growth of the orchardgrass plant. Other closely related endophytic fungi are known to produce alkaloids toxic to grazing mammals, but this does not appear to be the case for $E$. $t y$ phina in orchardgrass. We submitted two samples of tissue from heavily choked orchardgrass to A. M. Craig and J. T. Hovermale at the Oregon State University Veterinary Diagnostic Laboratory, where it was determined that the plant tissue contained no detectable ergovaline and $<300$ ppb lolitrem B (toxicosis is observed in animals feeding on material containing greater than 1,800 ppb lolitrem B [14]). Therefore, E. typhina probably does not pose a problem for livestock feeding of seed screenings.
It is clear that choke disease of orchardgrass is now well-established in this region, and its impact on seed production can only be minimized by developing and incorporating disease management procedures into cultural practices for this crop.

\section{ACKNOWLEDGMENTS}

We thank R. L. Cook (OSU Seed Certification), M. E. Mellbye, G. A. Gingrich, and S. AldrichMarkham (OSU Extension Service) for help with grower contacts and field location. We thank J. Ausk, S. Rothstein, O. Watson, and S. Seguin for technical assistance.

\section{LITERATURE CITED}

1. Alderman, S. C., Pfender, W. F., Welty, R. E., Mellbye, M. E., Cook, R. L., Spatafora, J. W., and Putnam, M. 1997. First report of choke, caused by Epichloë typhina, on orchardgrass in Oregon. Plant Dis. 81:1335.

2. Bacon, C. W., and De Battista, J. 1991. Endophytic fungi of grasses. Pages 231-256 in Handbook of Applied Mycology. D. K. Arora et al.; eds. Marcel Dekker, New York.

3. Bacon, C. W., and Hinton, D. M. 1991. Microcyclic conidiation cycles in Epichloë typhina. Mycologia 83:743-751.

4. Chung, K.-R., Hollin, W., Siegel, M. R., and Schardl, C. L. 1997. Genetics of host specificity in Epichloë typhina. Phytopathology 87:599-605.

5. Chung, K. R., and Schardl, C. L. 1997. Sexual cycle and horizontal transmission of the grass symbiont, Epichloë typhina. Mycol. Res. 101:295-301

6. Kirby, E. J. M. 1961. Host-parasite relations in the choke disease of grasses. Trans. $\mathrm{Br}$. Mycol. Soc. 44:493-503.

7. Large, E. C. 1954. Surveys for choke (Epichloë typhina) in cocksfoot seed crops 1951-1953. Plant Pathol. 3:6-11.

8. Leuchtmann, A., and Schardl, C. L. 1998 Mating compatibility and phylogenetic relationships among two new species of Epichloe and other congeneric European species. Mycol. Res. 102:1169-1182.

9. Leuchtmann, A., Schardl, C. L., and Siegel, 
M. R. 1994. Sexual compatibility and taxonomy of a new species of Epichloë symbiotic with fine fescue grasses. Mycologia 86:802812.

10. Raynal, G. E. 1991. Liberation des ascospores d'Epichloë typhina, agent de la quenouille du dactyle: Consequences pour l'epidemiologie et la lutte. Fourrages 127:345-358.

11. Sampson, K. 1933. The systemic infection of grasses by Epichloë typhina (Pers.) Tul. Trans. Br. Mycol. Soc. 18:30-47.
12. Schardl, C. L., and Leuchtmann, A. 1999. Three new species of Epichloë symbiotic with North American grasses. Mycologia 91:95107.

13. Sprague, R. 1950. Diseases of Cereals and Grasses in North America. Ronald Press Co., New York.

14. Tor-Agbidye, J., Blythe, L. L., and Craig, A. M. 1994. Correlation of quantities of ergovaline and lolitrem B toxins to clinical cases of tall fescue toxicosis and perennial ryegrass staggers. Pages 369-374 in: Plant-associated toxins: Agricultural, phytochemical and ecological aspects. S. M. Colgate and P. R. Dorling, eds. CAB International, Wallingford, UK

15. Western, J. H., and Cavett, J. J. 1959. The choke disease of cocksfoot (Dactylis glomer ata) caused by Epichloë typhina (Fr.) Tul. Trans. Br. Mycol. Soc. 42:298-307.

16. White, J. F., Jr. 1987. Widespread distribution of endophytes in the Poaceae. Plant Dis. 71:340-342. 